\title{
高齢者大腿骨頚部骨折術後の予後調查
}

\author{
徳島県立海部病院整形外科 \\ 岸陽子・浦岡秀行

\section{Prognosis of Femoral Neck Fractures in the Aged}

\author{
Yoko Kishi, and Hideyuki Uraoka \\ Department of Orthopedic Surgery, Tokushima Prefectural \\ Kaifu Hospital, Tokushima, Japan
}

\begin{abstract}
The prognosis of patients with femoral neck fractures who were over 65 years old was evaluated between three to four years after their operation. Thirty-three patients $(4$ men and 29 women, mean age, 83) who underwent surgery between November 1998 and November 1999 were included. A telephone survey was conducted on these patients or their families concerning the prognosis and their present state of ambulation. Fourteen of $33(43 \%)$ were deceased at the time of the follow-up. Among the remaining 19 patients, only $11(33 \%)$ were capable of ambulation and able to engage in social activities and 8 could not walk. Their present ambulatory state is influenced by their condition before the fracture. For example, $54 \%$ of the patients who could walk without the aid of devices were able to walk at the final follow-up. On the other hand, all patients, who were not capable of walking for social purposes, could not walk. Also influencing the prognosis was the patient's age when the fracture occurred. Among 13 patients over 85 years old, $69 \%$ were deceased by the final follow-up and only $16 \%$ were capable of ambulating for social purposes. Senile dementia is a crucial complication affecting one's ambulatory status after surgery. On the whole, only $14 \%$ were socially ambulatory, and all patients 85 or older with senile dementia could not walk at the time of the final follow-up.
\end{abstract}

Key words : femoral neck fracture (大腿骨䅡部骨折), prognosis (予後), aged (高齢者)

\section{は じめ に}

近年, 高齢化社会の進行が社会問題にまで発展して おり, 高齢者大腿骨頚部骨折患者屯年々増加し続けて いる. しかし, 本骨折患者が, 術後何年後によ゙の程度 の歩行能を再獲得し, よ゙の程度死亡しているのかを詳 細に示した報告は少ない.

本研究の目的は, 術後 $3 \sim 4$ 年経過した高齢者大腿 骨頚部骨折患者の生命予後, 再獲得した歩行能の推移 を明らかにすることである.さらに，歩行能再獲得を 妨げる因子についても検討を加える.

\section{対象および方法}

1998 年 11 月から 1999 年 11 月までに当科で手術加 療を行い, 2002 年 11 月の時点で術後 $3 \sim 4$ 年経過し た 65 歳以上の大腿骨頚部骨折患者 34 例のうち経過観 察し得た 33 例を対象とした。性別は男性 4 例, 女性 29 例. 手術時年齢は 69〜96（平均 83）歳であった. 骨折型は外側型 26 例, 内側型 7 例であった. 手術は, 外側型に対し 25 例に compression hip screw (CHS) 法を，1例に Ender 法を行い，内側型に対しては 4 例に Bipolar 型人工骨頭置換術を， 3 例に Cannulated Cancellous Hip Screw 法を行った. 


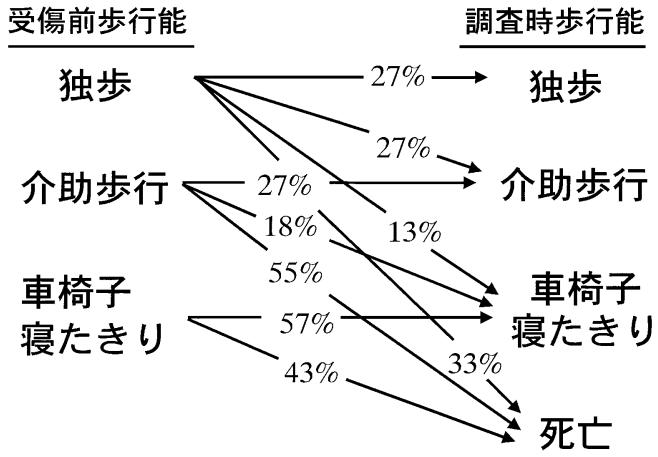

図 1 受傷前歩行能から調查時歩行能への推移

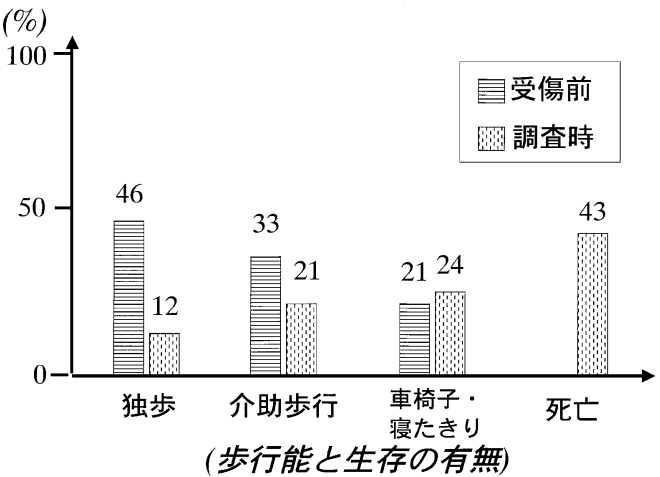

図 2 受傷前抢よび調査時歩行能の比較

対象患者に対し，電話にて生存の有無と受傷前およ び現在の歩行能力について調査した。

検討項目として，歩行能力を独歩，介助歩行（杖 老人車・歩行器), 歩行不能（車椅子・寝たきり）に 分け評価した。 また, 受傷前歩行能力・年齢・痴呆, これら 3 つの因子が術後の生命予後・調查時歩行能力 に与える影響を検討した。

結果

1. 受傷前歩行能力の影響

受傷前から調查時（術後 $3 \sim 4$ 年経過時）にかけて の歩行能の推移を見ると, 調查時歩行能は受傷前歩行 能と同レベルか受傷前以下のレベルへと推移していた (図 1 ). 調査時歩行能が受傷前歩行能より上がってい る症例は認めなかった。

受傷前および調查時歩行能の比較を行ったところ，

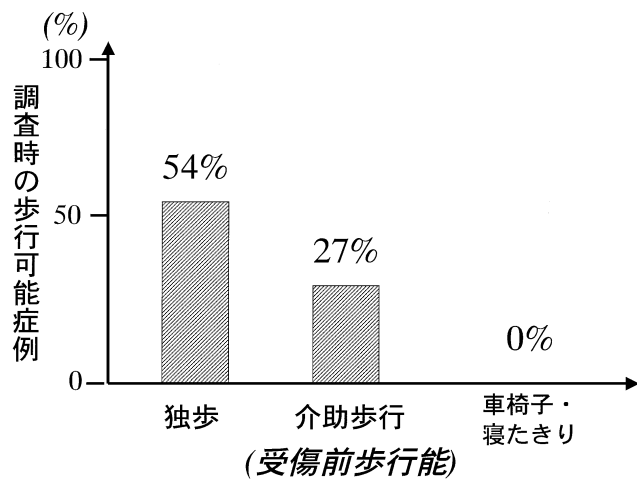

図 3 受傷前㧍よび調査時歩行能の関係

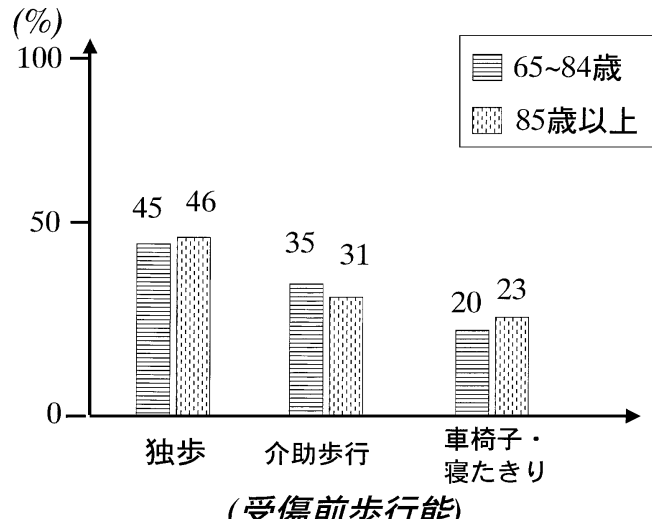

図 4 年齢で比較した受傷前歩行能

受傷前歩行可能（独歩，介助歩行）な症例が $79 \%$ た っ たのに対し，調査時に歩行可能な症例は $33 \%$ しか認 めず，調查時死亡率は $43 \%$ だった（図 2 ）。

受傷前㧍よび調查時歩行能の関係をみると, 受傷前 独歩症例では調查時に $54 \%$ が歩行可能であった。 ま た，受傷前介助歩行症例では調査時歩行可能な症例が $27 \%$ と独歩だった症例の半数であった。一方，受傷前 に車椅子・寝たきりの症例では, 調查時歩行可能な症 例は $0 \%$ であった（図 3 ). 術後歩行能再獲得には, 術前歩行能が大きく関与していた.

2。年齢の影響

対象を受傷時年齢により 65〜84 歳と 85 歳以上の症 例に分け歩行能の比較を行った。図 4 に見られるよう に, 受傷前では歩行能に両群間で大きな差は認められ なかった。従って，受傷前歩行能は，加齢による影響 


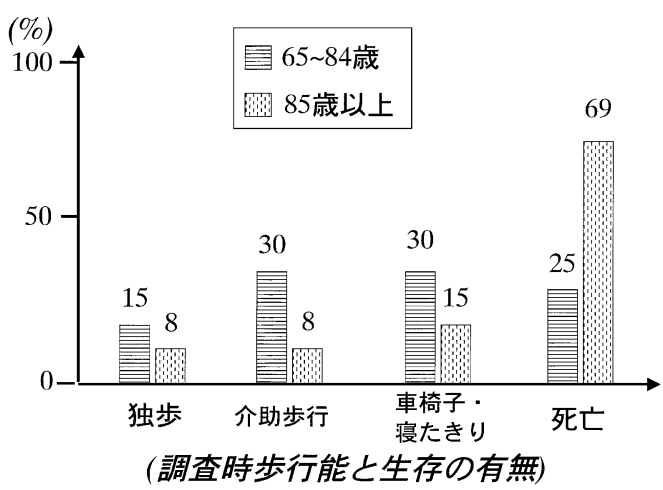

図 5 年齢で比較した調査時歩行能

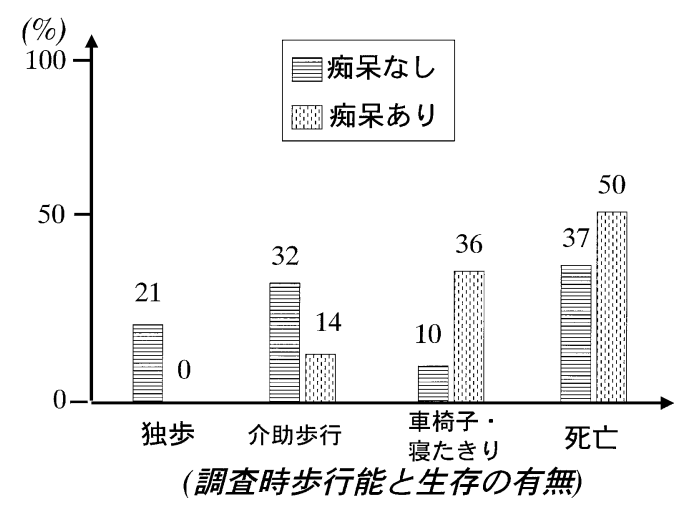

図 7 痴呆の有無で比較した調査時歩行能

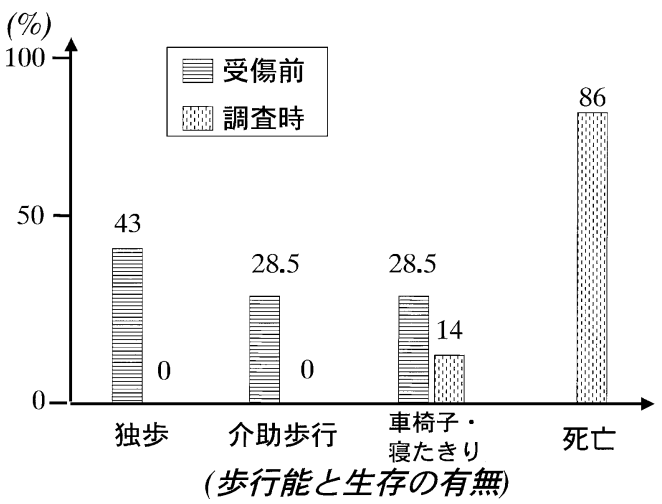

図 885 歳以上に打ける痴呆合併例の受傷前 および調査時歩行能の比較

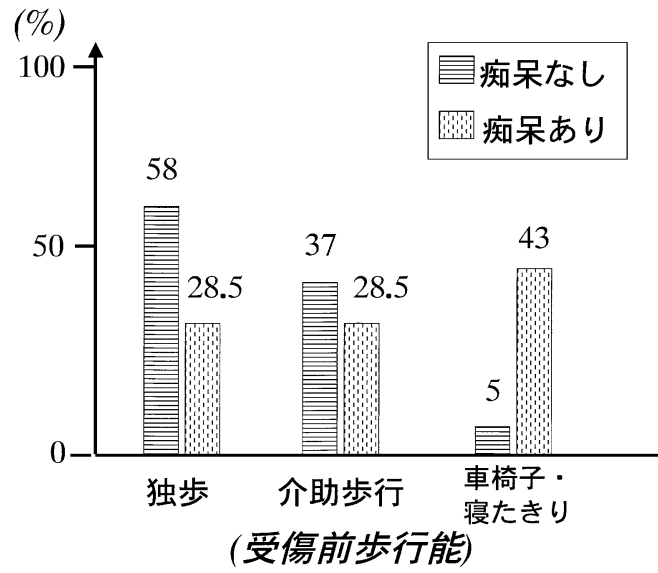

図 6 痴呆の有無で比較した受傷前歩行能

を受けていないことが分かる。一方, 調査時歩行能を 見ると（図 5 )，独歩症例はそれぞれ 15\%，8\%，介 助歩行症例は $30 \%, 8 \%$, 調査時車椅子・寝たきりは $30 \% ， 15 \%$ ，そして，調査時死亡症例は $25 \% ， 69 \%$ であった。 85 歳以上の症例では調査時死亡症例が 69 $\%$ 占め, 生存していた残りの症例 $31 \%$ うち車椅 子・寝たきりが約半数の $15 \%$, 歩行可能な症例は 16 \%にとどまった。これは，65〜84 歳群での調査時歩 行可能症例 $45 \%$ を大き下回る. 従って, 術後歩行 能再獲得において，年齢の影響が大きい事が分かる.

\section{3 . 痴呆の影響}

痴呆の有無で，受傷前歩行能の比較を行ったところ， 受傷前独歩だったのは痴呆合併していない症例が 58
\%に対し，痴呆合併例では $28.5 \%$ と約半数であり， また車椅子・寝たきりはそれぞれ $5 \%$ ，43\%と痴呆合 併例では受傷前から歩行能の低下が目立った（図 6 ).

同様に, 痴呆の有無で調査時歩行能の比較を行った ところ, 調査時歩行可能（独歩および介助歩行）であっ たのは，痴呆合併していない症例では $53 \%$ だったの に対し，痴呆合併例では $14 \%$ にどまった（図 7 ). すなわち, 痴呆の合併は, 術後歩行能再獲得に与える 影響が大きいことが分かった。

さらに，85 歳以上の痴呆合併例に限定し受傷前お よび調査時の歩行能の比較を行ったところ，歩行可能 (独歩十介助歩行）であったのは，受傷前 $71.5 \%$ だっ たのに対し，調査時では皆無であった（図 8 )。また 
調査時死亡症例が $86 \%$ と高率であった.

\section{考察}

今回, 65 歳以上の大腿骨頝部骨折患者の術後 3 年 から 4 年の予後を調査した。 その結果, 調査時歩行可 能な症例は $33 \%$ ，死亡症例は $43 \%$ であることが分か り，長期にわたり良好な歩行能を維持する事は困難で ある事が明らかとなった，さらに，長期歩行能を低下 させる因子として以下の 3 因子が明らかとなった。

1 ）受傷前車椅子・寝たきりの症例

2 ） 85 歳以上の症例

3 ）老人性痴呆の合併症例

受傷前車椅子・寝たきりの症例で調査時歩行可能と なっている症例は皆無であった。また，年齢が 85 歳 以上で調査時歩行可能な症例は $16 \%$, 痴呆を合併し ている症例で調査時歩行可能な症例は $14 \%$ にとどまっ た。さらに 85 歳以上の痴呆合併例では，調査時 $86 \%$ が死亡，14\%が歩行不能であり歩行可能な症例は皆無 であった。

現在，高齢者大腿骨頚部骨折は年々増加の一途をた ぞっており，本疾患に対し多くの施設では観血的治療 が第一選択されている。使用される implantには高 価な人工骨頭む含まれており，このことが老人医療費 高騰の原因に大いに関与していると思われる.

高齢者大腿骨頚部骨折の歩行能の長期予後が不良で あると言う本研究結果をふまえ，本疾患における使用 implant の機種を再考する必要があると思われる．現 在，大腿骨䅡部内側骨折に使用されている人工骨頭は， 長期耐久性を追求した高価な Bipolar 型が主流である. 一方, Austin-Moore に代表されるMonopolar 型人 工骨頭は，対象を活動性の低い大腿骨頚部骨折患者は あちろんのこと ${ }^{1,4)}$, 比較的活動性がある症例にも良
好な治療成績が報告されている ${ }^{2)}$. 従って, 長期予後 が期待されない高齢者の大腿骨頚部骨折の治療で使用 する implantの機種として Monopolar 型人工骨頭が, あう一度見直されてもいいのではないかと思われる。 特に今回の結果より，1）受傷前歩行能力が低い，2） 85 歳以上，3）痴呆合併，これら 3 点のいずれかが 見られる症例では，良い適応であると思われた。

疾患別包括支払い制度が，本年より特定機能病院で 導入され，医療費の支払いが出来高払いから定額払い に変わった。つまり治療した疾患により，一定の支払 い額が決定される。このシステムでも手術は出来高算 定されるが，日本の医療制度が改革されつつある今， 本研究を通し，コストパフォーマンスを考慮した治療 を行う必要性を強調したい ${ }^{3,5)}$.

\section{ま と め}

高齢者大腿骨頚部骨折において，1）受傷前歩行能 力が低い，2）85歳以上，3）痴呆合併の 3 点のい ずれかが見られると，術後歩行能再獲得の妨げが大き くなると考えられた。

\section{文}

\section{献}

1) Eiskjaer, S., et al. : Survivorship analysis of hemiarthroplasties. Clin. Orthop., 286 : 206-211, 1993.

2）後藤 学, 紫藤徹郎, 井上喜久男ら：大腿骨頝部骨折 に対する Austin-Moore 型人工骨頭置換術の検討。中部 整災誌，41：153-154，1998.

3）浜西千秋：大腿骨䅡部外側骨折の保存療法. 整 - 災外, $44: 813-819,2001$.

4）宮岡英世，立岩正雪：Monopolar 型人工骨頭置換術の 成績。骨・関節・勒帯，13：393-398，2000。

5）中野哲雄, 阿部靖之, 清水泰宏ら : 大腿骨䅡部内側骨 折の内固定術．整・災外，44：821-828，2001. 